\title{
Unveiling social awareness through literacy practices in an EFL class
}

\author{
La conciencia social a través de prácticas \\ de alfabetización en un salón con inglés como idioma \\ extranjero
}

\author{
Luzmel Alexánder Pérez Pérez \\ Universidad Distrital Francisco José de Caldas \\ luzmelp1978@yahoo.com.ar
}

Received: 3-Jun-2013/Accepted: 16-Oct-2013

\begin{abstract}
This qualitative research study addresses issues of verbal and physical aggression among tenth grade students in a public school. Through a pedagogical intervention the participants worked collaboratively to reflect on social issues in their English language classes. Inquiry was a fundamental element in this study as it allowed students to explore, read, compare, and then reflect on issues that come from their own context and experiences (Giroux, 1988). Students' reflections were collected through questionnaires, artifacts, and audio recorded interviews in order to gather information to reveal students' social awareness of physical and verbal aggression in their school context. The findings revealed that students see violence as a need to avoid their partners' abuse. Students' reflections showed that students considered that parents and teachers paid more attention to academic concerns, rather than personal growth. The study demonstrated that inquiry along with writing about social issues in English allowed students to develop rationality and sensitivity towards violent acts, furthermore, inquiry about their social problems encouraged students to work collaboratively, to reflect about their social conditions and to apply the use of the English language in contextualized situations.
\end{abstract}

Keywords: social issues, inquiry, verbal and physical aggression, social awareness, reflection.

\section{Resumen}

Esta investigación cualitativa aborda temas de agresión verbal y física entre estudiantes de grado décimo de un colegio público. A través de una intervención pedagógica los participantes trabajan colaborativamente para reflexionar sobre problemáticas sociales en sus clases de inglés. La indagación fue un elemento fundamental en este estudio ya que permitió a los estudiantes explorar, leer, comparar y luego reflexionar sobre situaciones que surgen de sus propias experiencias y contexto (Giroux, 1988). Las reflexiones de los estudiantes fueron recopiladas a través de cuestionarios, producciones de clase y grabación de entrevistas con el fin de recoger información que revelara la consciencia social de los estudiantes sobre las agresiones verbales y físicas en su colegio. Los hallazgos revelaron que los estudiantes ven la violencia como una necesidad para evitar el abuso de sus compañeros. Las reflexiones mostraron que los estudiantes consideran que los padres y profesores prestan más atención a la parte académica que al crecimiento personal. El estudio reveló además que la indagación junto con la escritura acerca de problemáticas sociales en inglés, les permitió a los estudiantes desarrollar racionalidad y sensibilidad hacía los hechos violentos, además de motivarlos a trabajar colaborativamente para reflexionar sobre sus condiciones sociales y poner en práctica la lengua inglesa en situaciones contextualizadas.

Palabras claves: problemáticas sociales, indagación, agresión verbal y física, consciencia social, reflexión.

\section{Résumé}

Cette recherche qualitative porte sur des questions d'agression verbale et physique chez les élèves de dixième année dans une école publique. Grâce à une intervention pédagogique les participants travaillent en collaborant pour réfléchir sur les questions sociales dans leurs cours d'anglais. L'enquête a été un élément clé dans cette étude car elle a permis aux élèves d'explorer, lire, comparer et puis réfléchir sur les 
situations qui découlent de leurs propres expériences et le contexte (Giroux, 1988). Les réflexions des étudiants ont été agrouper au moyen de questionnaires, des productions de classe et des interviews d'enregistrement afin de recueillir des renseignements qui révèle la conscience sociale des élèves au sujet de la violence verbale et physique à leur école. Les résultats ont révélé que les élèves voient la violence comme une nécessité pour éviter les abus de leurs pairs. Les réflexions ont montré que les étudiants croient que les parents et les enseignants accordent plus d'attention à la partie académique qu'à la formation personnelle. L'étude a également révélé que l'enquête avec l'écriture sur les questions sociales en anglais, les élèves ont été autorisés à développer la rationalité et la sensibilité vers la violence, motivés à travailler en collaboration afin de réfléchir sur leurs conditions sociales et mettre en œuvre la langue en des situations conceptualisées en anglais.

Mots-clés: les problèmes sociaux, l'enquête, l'agression verbale et physique, la conscience sociale, la réflexion.

\section{Introduction}

The social reality observed in public institutions of Bogota is a problematic situation that in recent years has called the attention not only from schools but from the government, teachers and parents. Issues like verbal and physical aggression are social realities that in poor areas tend to be more conflictive, moreover when the young population belongs to deprived communities with economic crisis, dysfunctional families and violent concerns (Millan, 2010). These social realities suggest that content area teachers from public schools cannot overlook social situated aspects and must assume the challenge of involving social issues analysis as part of the curriculum. This study implies that learning English as a foreign language (EFL) cannot only be the way of coding or decoding symbols (Lerner, 2001), instead, it must point to see literacy as a social practice (Baynham, 1995) with a social responsibility, that associated with inquiry (Short, Burke, \& Harste, 1996) serve students of the public sector as a means of exploring and reflecting about their social context; which according to Freire $\varepsilon$ Macedo (1987) must be the purpose of language.

Considering the importance of social contexts in our educational settings, the purpose of this study was to conduct a qualitative research in a public school located in the neighborhood of Usme, in the southest part of Bogotá, Colombia, aiming at revealing students' awareness about their social realities while inquiring their context and developing their EFL skills. This, to respond to the questions: what do EFL students' written reflections reveal about their social awareness when inquiring about verbal and physical aggression at Tejares public school and how do students develop their EFL writing skills when inquiring about verbal and physical aggression inside their institution?

The interest of this research was framed under the concepts of inquiry Short (1996), social awareness (Selman, 2011; Durlak, 1996; De Angelis, 2010) - social issues (Spillane, 2000; Shepard, 2000) and literacy (Baynham, 1995; Lerner, 2001; Freire \& Macedo, 1987), that supported this study and permitted the connection between context and EFL learning.

\section{Social awareness}

Social awareness in general terms is related to the understanding, behavior and commitment of a person with his or her society. This idea may vary from person to person and especially with population immersed in conflictive environments. To this regard, Durlak (1996) considers that social problems can be addressed if people are taught to think and to look for solution to their own difficult realities. The author defines social awareness as the human ability to be conscious of the problems that an individual, society, or community faces in different contexts (politics, religion, arts, and philosophy). This conception proposes that social difficulties take place when people are not aware of their problems and duties as members of a community. Difficulties that were observed in the context of this research along 
with other aspects like culture, ideologies, differences and other tendencies that make interaction among students more difficult.

From a different perspective, De Angelis (2010) proposes that working on social awareness is important to reduce violence index. She explains that a person can be socially aware, but there are emotions that make people react violently because of situations that get out of control. As previously mentioned by the author, institutions and mainly teachers from public education should consider the emotional state of students since it might be a cause of their aggressive behaviors. Based on the previous concept, it is possible to say that one mission of schools may be to help students regulate their emotions and guide them through activities that involve problems related to their realities.

Additionally, Selman (2011) adds that social awareness must be one of the fundamental missions of schools, and that it needs to be woven into much of the daily school activities. He proposes activities like caring for and educating communities by forming group activities such as classroom meetings in which people deal with disagreements. Another activity focuses on encouraging cooperative learning tasks, as well as reading texts that focus on social and ethical issues familiar to students' context.

From a different position, Csóti (2009) and Durlak (1996) propose that social awareness should not necessarily fall entirely on teachers' shoulders. It means that students may assume responsibilities of their own behaviors. Regularly, students assume some rude attitudes because they do not consider certain behaviors, such as insulting or hitting people, a social issue. These attitudes must be supervised not only by teachers and require a serious involvement, firstly from parents, then, the institution to make students recognize that social issues affect their lives as students and as members of a society.

Consequently, it is important to involve social awareness activities in public institutions where students share, face and analyze hard social, familiar, personal and even political conditions. At the local level, Parga (2011) developed a study in which the use of cooperative learning along with the awareness of social problems resulted as an alternative for students to cope with interpersonal conflicts in a public school. In general, the author pointed out the positive impact of engaging his students in activities in which the study and reflection of social conditions; benefit the target language (TL) learning in a classroom and contribute to the social formation of every individual. From a similar view, Bello (2012) carried out a research in which project based learning (PBL) and the reflection and discussion on social concerns allowed her students to enhance a critical view and a social transformation in their society while studying the target language. The intention of this research work coincides with Parga and Bello in considering the EFL learning process as a social mechanism that permits the learner's formation, analysis and social commitment while studying the language.

From an international context, Ho (2010) developed a research in which literacy and social context revealed that social conflicts can be appeased if human beings are guided and modeled by adult referents. The author found that most of the social problems emerge from the bosom of each family and that students reproduce what they face in different contexts: culture, literacy, technology, and religion among other contexts. Nevertheless, she pointed out that family must guide children in the processes of awareness in order to avoid social shocks. Family is then a powerful stimulus in developing culture, values, and behaviors among members.

Similarly, Hindin's research (2010), a project that highlighted the importance of linking community to school activities to make students reflect on their problems, coincides with $\mathrm{Ho}$ (2010) in saying that any type of change (personal, educative, technological, and social, among others) require special supervision from family. The involvement of family was important 
in this research since the institution recognized that most students' aggressions took place because of the lack of attention and guidance from parents and teachers. These reasons were shown in some of students' writings.

To conclude the idea of social awareness, the researchers found the role of parents essential, as they are the first referents for children in the construction of values, knowledge, and language, among other aspects of life formation and that in hard environments; parents must be the first to guide their children and teachers become facilitators of spaces for those changes. The panorama presented by the former researchers demonstrated that social awareness is not a topic but a social situation that needs to be addressed in the classrooms. It is also an issue that serves teachers to use different methodologies and strategies to teach and learn a language by using the students' context. These ideas result interesting and nurture the intention of this study since the social conditions, language learning and literacy practices are part of the learner environment and directly affect his or her EFL process.

\section{Social issues}

The social reality in the classrooms of public institutions in Bogota is a situation that affects not only the academic environment but the social structure of our society (Shepard, 2000). Social issues are defined as problems that directly or indirectly affect the members of a community or society (Suivid 2008), which is the situation observed in this study.

The emphasis on working with issues like verbal and physical aggression was thus an attempt to engage students in processes of reflection, analysis and possible actions; where they connect their social realities with the TL knowledge. According to Facione (1998), linking contextualized situations in class environments opened spaces for reasoning and critical thinking, concerns that must be considered in the processes of teaching and learning. Correlating this idea, Spillane (2000) suggests that schools are sacred places of formation that have the obligation to see students' context as part of their educational instruction, placing them also as the first participants in providing reflection and solutions.

In addition, McLaren (1989), Green (1998) and Giroux (1988) state that education in schools goes beyond the responsibility of providing students with instructional learning. So, teaching and learning processes cannot be separated from students' real life. The scenery presented by the former authors highlights the importance of placing students as active participants of their own change. Especially, when they belong to low socio economic levels with lower quality of life, violence and dysfunctional family problems among other issues that make their lives difficult at school and in their communities.

Taking into account the strong connection between learning and social context, this study focused on students' reflections about physical and verbal aggression, which are the two main social issues presented as a problematic situation in a public school of Bogotá. Spillane (2000) conceives aggression as a natural behavior, properly of humans and animals whose intention is to harm or cause pain to others. The concept of aggression concludes that humans as well as animals react violently at certain moments in life, with the difference that humans have the ability to control themselves and sometimes their situations. This idea explains that aggressive acts are part of social interactions, and can be motivated by different circumstances like family structure, sex, and age, among other circumstances. For the author, aggressive acts could have a certain justification since those acts are normal in all species; however, they need to be controlled, especially by teachers in educational settings.

Sharing the same view, Durlark (1996) invites us to see the act of aggression as a condition that humans use to dominate others. Issues like cheating, deceit, or negotiation, for example, are used to obtain 
status, benefits, or valuable resources from other people. The previous information suggests that aggression is not only understood in terms of physical but psychological and/or emotional harm, which students may use as a way to get rid of their own problems. So, in this study, the term aggression is considered as a personal act that is present in every individual and that invites teachers to find strategies to make students negotiate alternatives different from verbal or physical violence.

Lewis and Bernstein (2009) carried out a research focused on sexual orientation issues with the intention of helping students reflect, understand and opine about those issues by linking social concerns with their lessons. In their proposal the researchers made students explore, communicate, interact, and interview people with different sexual orientations, as well as parents and other students. The researchers concluded that the best way of helping students face social problems is involving them in the solutions.

Marshall and Klein (2009) did a study in which the main focus was to promote civic engagement. They developed their research by involving students in a process of reflection and reading and writing about issues of social justice and political concerns that were present in the students' context. This study shows that taking advantage of students' context can guide academic processes inside classrooms.

The former studies stand out that the real context provides content for the classes, but it also allows for deep reflection on the students' side. According to Facione (1998), reflections involve stages of high reasoning such as interpretation, analysis, and inference. These characteristics make the act of teaching more contextualized and consequently, more meaningful. In this research work, the use of students' context looked for the observation, interpretation, analysis and awareness from students; by doing their own research on verbal and physical aggression.

\section{Literacy}

Nowadays the concept of literacy goes beyond the ability to read and write (Lerner, 2001; Olson \& Torrance, 1995 \& Teutsch 1997). This concept has become strong enough to assert that literacy is a social practice that is present in the everyday life of humans Baynham (1995), and it is an opportunity for people to emancipate, express or have a voice in society (Freire $\mathcal{E}$ Macedo, 1987). Taking into account the panorama framed under the vision of literacy, this study considered reading and writing as an opportunity for students to reflect and express a critical vision of the verbal and physical issues they face in their school. For Phillip (1998), literacy is an ability that through the time has an impact in society, so, it needs to be fostered at schools and teachers are responsible in instilling it.

Related to the role of teachers in the process of teaching, authors like Lerner (2001) and McLaren (1989) emphasize the importance of incorporating students in a culture writing process where students interact in their communities, involving context and social practices through written forms. It is important then, to recognize that knowledge is practical when interactions and behaviors, as part of students' lives, are involved in the curriculum. When real contexts are the core of education, ideas of transformation or emancipation can occur (Freire E Macedo, 1987).

For this research study, working with contextualized situations is necessary since social issues like physical and verbal aggression are a social problem faced by students in the public school sector. In addition to literacy and social context, Jockson (2006) conducted a research work that involved poetry and students' social context. This research work demonstrated that students' literacy practices associated with social context were valuable for them to gain writing skills, confidence in learning, self-awareness and social conscience. This research study permitted also to recognize that the class contents cannot be isolated 
from students' realities, otherwise, learning and teaching practices are not meaningful for students and even for teachers.

Furthermore, Hull and Shultz (2001) developed a study about the importance of expanding literacy beyond the classroom. They took into consideration home, neighborhoods, and other settings that are in students' context; to make them learn by using their own situations. In the studies developed by Jockson (2006) and Hull and Shultz (2001), the authors saw the idea of connecting outside literacy (literacy practices that take place at home and in neighborhoods) as a powerful strategy to enhance reading and writing skills in a classroom. They also discovered that teachers sometimes ignore or consider unnecessary weaving social aspects into the teaching and learning processes.

Summing up, literacy is meaningful as its goal is to take advantage of the language to make students interact, and to contribute to their communities as social members. Teachers must recognize that literacy is a practice that is developed in different contexts: at home, at work, in restaurants, etc., that are part of each individual's life. Literacy is then a skill with a social purpose; a skill that offers students the opportunity to learn, interpret, analyze and make decisions that benefit their own and collective purposes. For this research work, literacy is more than one academic content, it is a life's tool. This concept of literacy contributes to the purpose of the project along with inquiry, which is better defined in the upcoming lines.

\section{Inquiry}

Inquiry is mainly understood as the process of solving a problematic situation by means of the observation, analysis and development of strategies that satisfy people's curiosity. In educational settings, inquiry facilitates personal explorations and encourages students to discover and solve personal interests while learning specific stuff from a subject (White E Fitzsimmons, 2005). This study considers that inquiring on physical and verbal aggression contributes to the analysis of a social situation, but also, it offers the students the opportunity to link their literacy practices while inquiring their context. Social realities like aggressions, for example, are issues that most students live with and they serve as a topic for learning, exploring and realizing what is really happening in their lives and contexts. To this respect, Uno (1990) considers that inquiry is a way for people to discover things or to confirm facts that were not clear.

Additionally, inquiry points out that humans have an intrinsic curiosity that motivates them to inquire about what is around us (Short et al., 1996). Questioning, for example, has been a reason for people to explore things that once were beyond their imagination. This is a premise that turns inquiry meaningful; otherwise, inquiry is just a simple consult of a topic. This idea of inquiry is correlated with Bibens (1980), who defines it as a desire of learning by searching for things in real contexts.

The former theory considers inquiry as a way to explore social topics in teaching and learning practices. By doing this, it is expected that students establish a bridge between the school and the community. Inquiry provides an alternative for students to observe, analyze, and propose reflections about social issues that occur in their own environment; from the teacher's view it is also a strategy to expand knowledge by using students' own experiences and context. Authors such as Roberson and Bloome (1998) and Banchi and Bell (2008) consider inquiry a way to make students aware of their own realities and as a natural process that looks for the satisfaction of peoples' curiosity.

To conclude, inquiry satisfies personal interests and motivates people to discover new things by observing, exploring, analyzing and proposing possible solutions to a problem. This concept of inquiry is valuable and necessary to carry out the methodology of this study. 


\section{Methodology}

This research work is embodied in the principles of qualitative, descriptive, and interpretative study (Gay, Mills, E Airasian, 2009) and an inquiry approach (Short et al., 1996) to describe students' social interactions, reflections and awareness through reading and writing practices in EFL. The participants were a coeducational group of 40 tenth graders in the morning shift at a public school in Bogota, whose ages ranged between 16 and 20 . The students were comprised of 21 girls and 19 boys. They presented similarities of low language proficiency, age and low socioeconomic conditions. To make data collection easier, the group was divided into 12 groups. The selection of these participants was mainly because I was teaching them English and because this particular group had been involved in continuous problems of aggression. They had three hours of English per week, which allowed me to gather data for three months.

\section{Ethical Considerations}

The students' parents and the institution were informed about the study. During the first parents' meeting at school, inquiry was introduced as a strategy to cope with social and EFL learning issues. They agreed and authorized their students to be part in the research. The parents were told about the purpose, process, data collection, privacy and confidentiality of their students' comments. Consequently, they signed up a consent form (Appendix 1).

\section{Data Collection Instruments}

Data were obtained by means of questionnaires, artifacts, and semi-structured audio recorded interviews with forty participants. These instruments were selected because they seemed to be the most efficient and practical for the purpose of the study. Following Burns (1999), questionnaires facilitated the data collection because they saved time, did not need transcribing and could be applied at different moments and with several groups at the same time. In the case of this study, questionnaires were developed in and out of the classroom because of time considerations. This instrument permitted this study to carry out six questionnaires in which students expressed their opinions about situations related to physical and verbal aggression.

Artifacts, the second instrument, were a concrete and physical evidence of what the participants carried out through the process of reflection. Artifacts complemented the information given in other sources like questionnaires and interviews (Burns, 1999). The use of this instrument during the research process was mainly because of the flexibility of its implementation. Students made artifacts like portfolios, reports, and personal writings (Freeman, 1998). Most of the activities found in the artifacts were done in and out of the classroom.

Interviews were done with the purpose of informing the researcher about students' insights regarding their attitudes, actions and comments about aggression acts they observed in their context (Freeman, 1998). This research applied three different audio- recorded and semi- structured interviews, using open-ended questions in Spanish at the beginning, in the middle and at the end of the implementation. This type of interview facilitated the work with students since they were flexibly-worded and not formal (Burns, 1999). This research allowed students to work on their own interviews as part of one of the steps of the inquiry cycle (Gaining a new perspective an attending the difference) (Figure 1) that permitted them to explore and formulate questions for their teachers, parents and students as part of their inquiry interest.

In order to assure reliability, the data was consistently and systematically grouped, analyzed and placed in categories, pointing out the information that showed students' social awareness (Strauss and Corbin, 1990). The subsequent process to the analysis of the data consisted in reading and rereading the information provided from the different instruments. Later, the data were grouped taking into 
account commonalities among the information and, progressively, the information was narrowed down until getting a phrase or statement which better enclosed students' responses.

\section{Pedagogical Intervention}

In this research, the institution, parents and learners approved of the idea of developing a study focused on students' reflections about social issues to explore and enhance the students' social awareness. To achieve this goal, I proposed an inquiry cycle (Figure 1 ). The cycle started by making students observe a problematic situation in their context, then, they analyzed causes and possible solutions; later on, they posed a research question, found information, gathered and analyzed data and presented results to the problem they proposed. As short (1996) states, inquiry procedures are helpful for teachers to guide class activities in which students follow, develop and organize their research according to the cycle proposed. This cycle permits that students observe, find, understand their context and work cooperatively.

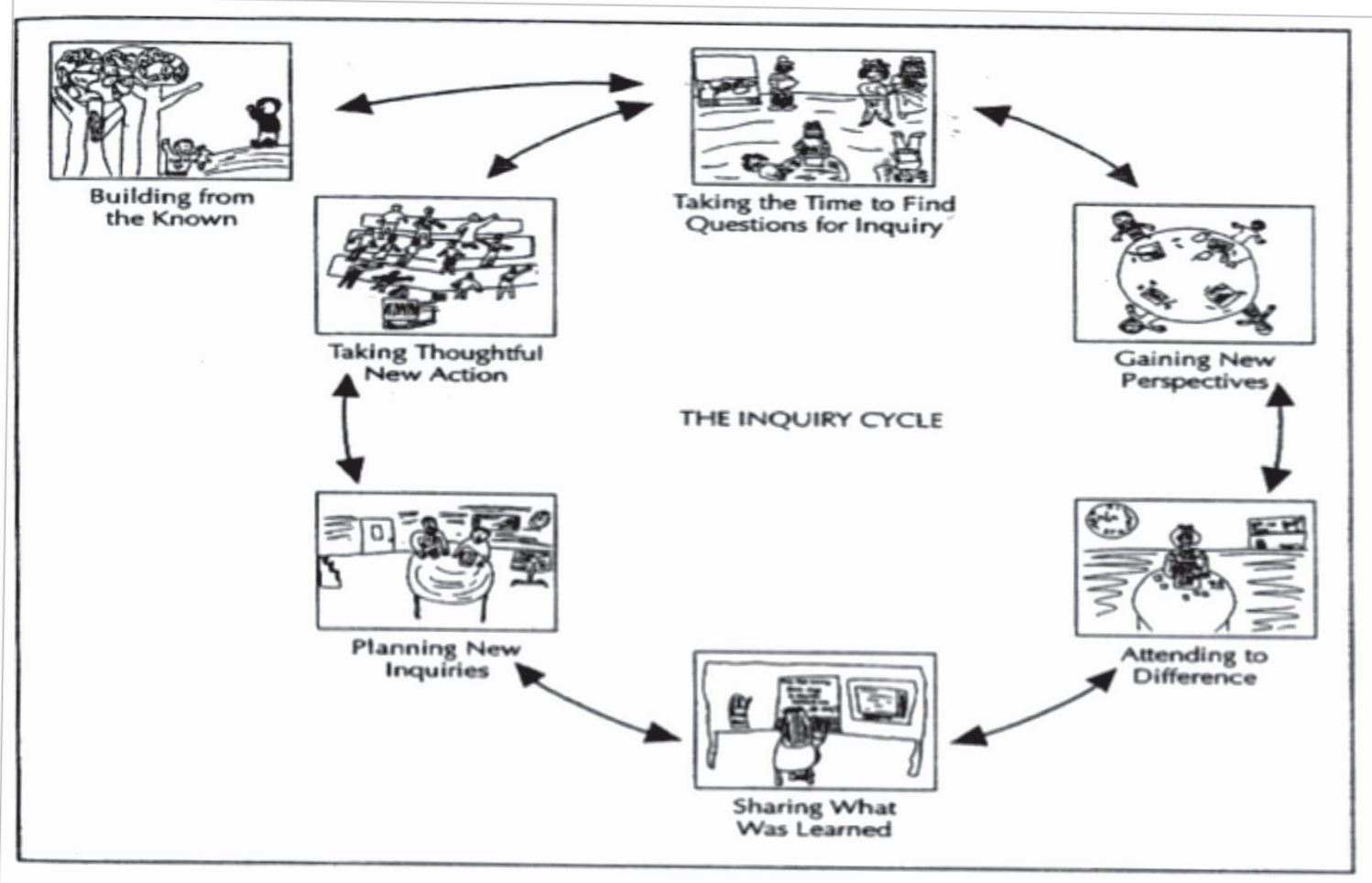

Figure 1. The authoring cycle model (Short, 1996, p.262)

In short, the pedagogical intervention consisted of ten lessons (Appendix 2), adapted from the authoring cycle of inquiry (Short et al., 1996) which involves and guides the students in a process of research, based on verbal and physical aggression; a problem students observed and selected as a topic to explore in their school context. This intervention involved observation, discussion, consulting, interviewing, team work, reading and writing from students' interests. It was a participatory activity in which the whole class worked on, linking their context and their English knowledge.

As my aim was to unveil students social awareness of their social conditions and encourage them to use the TL, it is pertinent to say that students used their mother language too, because there were 
some activities in which they felt more comfortable by speaking or writing in Spanish. Using the L1 and the L2 during the process of inquiry allowed students to understand aspects like grammar and tenses usage in both languages. This intervention facilitated the articulation between context and language, but also fulfilled the purpose of literacy; which according to Olson and Torrance (1995) and Lerner (2001), looks for the development of writing and reading abilities that involve cultural, social and context aspects; if not, literacy turns into just the acquisition of codes (Freire $\mathcal{E}$ Macedo 1987).

\section{Findings}

The data analysis process shown in Figure 2 was carried out based on the grounded theory approach. This approach was suitable since it emerges from the data gathered and facilitates interpretation and theorizing about the information collected during the research process. The analysis of the data begins with coding, which consists of breaking down, examining, comparing, conceptualizing and categorizing data (Strauss \& Corbin 1990). The categories arose after organizing the data provided in questionnaires, student artifacts, and interviews; responding to the two initial questions of this research study.

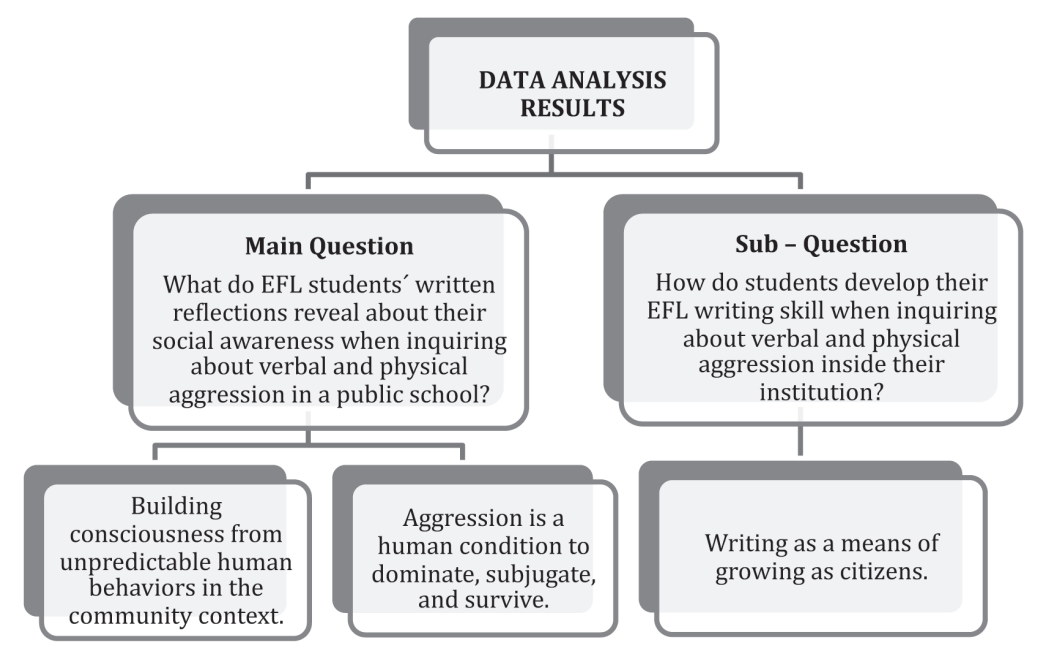

Figure 2. Categories derived from the data analysis

\section{Building consciousness from unpredictable human behaviors in the community context}

Using the concept of consciousness, understood as the connection between emotions and social interactions (Selman 2011), this first category shows students' learning from aggressive situations they observed and lived with at school and the way they handled them. Through the information gathered in students ' artifacts, interviews and questionnaires, students showed that aggression happened unpredictably. It means that an insignificant event can end in an aggression, which in students' context is a common fact that can be positive or negative and sometimes depends on external situations that affect their feelings and attitudes. Also, students' responses stated that aggression was as a way of liberating from their problems or emotions. Later on, they recognized that aggression was generated in part by the lack of self-control and that it was not necessary in a learning context, which revealed their social awareness.

Table 1 displays ideas from three groups of students whose texts describe their perception about aggression. As shown in the excerpts from groups 12 
and 10, they recognized and stated that aggression was part of the school context and happened when students interacted with people who had some disabilities and behaviors that caused sudden alterations in a group, and whose reactions ended in aggressions; which was not accepted by most of the students. On the other hand, Group 4 pointed out the importance of highlighting positive aspects of aggressors. Students explained that teachers and classmates labeled some students as aggressors because they did not really know who they were and how they perceived life. Students commented that teachers rarely took the time to dialogue or find out the reason of their behaviors. Selman (2011) and De Angelis (2010) consider that social awareness is developed when humans recognize the bad actions or conditions that affect people, societies, and communities every day. In this case, participants showed their awareness by recognizing that being rude to special needs kids, for example, was a way of violence in their institution.

Table 1. Excerpts from groups 4, 12 and 10 to illustrate the first category.

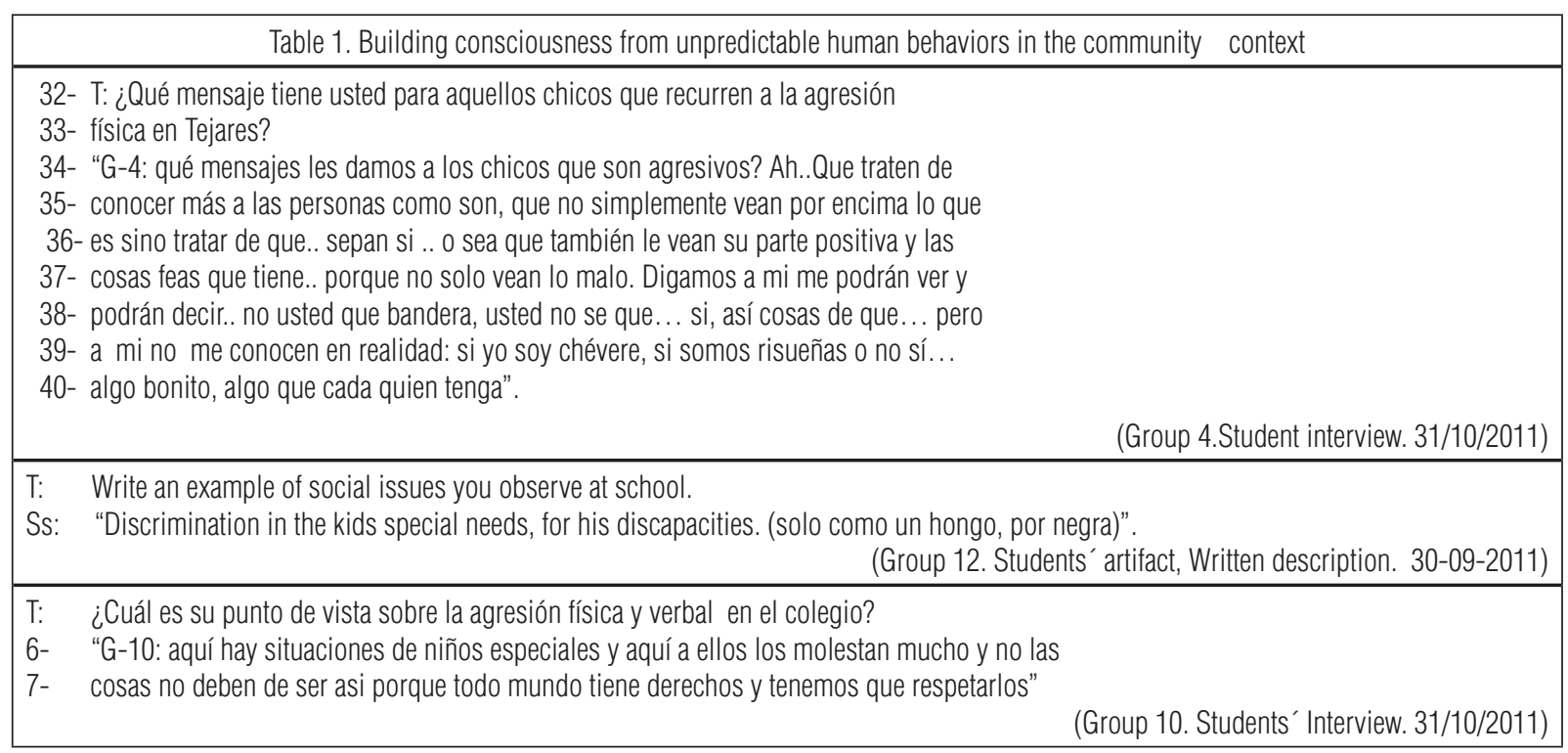

The findings also reported that there were some unpredictable situations like emotional states that appeared during aggression acts, and that could be positive or negative from person to person. In table 2, students recognized the importance of avoiding troubles. They manifested that some aggressions were not necessary if students first thought about the consequences of an action. The excerpts revealed that aggression was connected to physical and emotional harm. In excerpt 9, students gave their opinions taking into account experiences they observed in their institution. They considered that moral, physical and even legal issues were consequences of an act of aggression, consequences that probably some of them did not keep in mind when having an aggressive reaction. In Groups 4 and 7, students determined that aggressions were closely related to a psychological state, they considered that students assumed an aggressive behavior to excel or get recognition in their group, or maybe because it was the way to let their emotions out. On the other hand, one of the students in Group 4 stated that she could not avoid being aggressive, however she pointed out the importance of thinking before reacting. 
Table 2. Excerpts from groups 9, 4, 7 and 6 to illustrate the first category.

Table 2. Building consciousness from unpredictable human behaviors in the community context

T: ¿Qué queda después de un hecho de agresión y hacia dónde lo conduce?

"G-9: Después de las agresiones quedan tanto los daños físicos como morales. Dichos daños nos conducen a un problema mayor o hasta judi ciales. Por eso a pesar del problema lo mejor si es mejor pensar las cosas antes de hacer algo".

(Group 9. Students' artifact, written reflection. 21/10/2011)

5- T: cuál es su punto de vista sobre la agresión física o verbal en el colegio?

6- Ss: G- 4:yo no evito, yo soy muy agresiva, pero nosotros deberíamos evitar.. osea

7- tratando de dialogar mas yo no se es que.. haciendo actividades donde uno se pueda

8- integrar mas.. . si o sea que,, si osea entre grupos aveces no queremos.. osea no

9- podemos convivir digamoslo asi,, entoes tratar de que unirnos y tratar de

10- ver también las cosas positivas que tienen las otras personas y asi

( Group 4. Student's Interview 08/11/2011)

T: Cuál es su punto de vista sobre la agresión física o verbal aca en el colegio?

G7: yo creo que es algo más psicológico que físico, es algo más de que las personas piensan... no si yo le pego a este entonces todos van a decir que yo soy el duro, que soy el malo el que... si... y sí... pero muchas veces no piensan en las consecuencias.

(Group 7. Student's interview. 31/10/2011)

T: $\quad$ Cuál es su punto de vista sobre la agresión física o verbal aca en el colegio?

G-4: uno espera una pelea y después si se reconcilia porque uno tiene que sacar toda la furia que hay dentro entonces toda la rabia la saca asi, aveces sin pensar.

(Group 6. Student's interview. 31/10/2011)

Summing up, this category showed that aggressions and reactions were unpredictable situations students sometimes used as means of escaping from their emotions, or other personal realities they coexisted with. Learners also pointed out that teachers and even students should know more about aggressive people before labeling them as such. These previous comments were evidenced in the end of the cycle of inquiry (Taking Thoughtful New Action), in which the students expressed their analysis of the process and suggested ideas to help people who were aggressive at school.

\section{Aggression is a human condition to} dominate, subjugate, and survive

The data grouped into this category described aggression as a way of getting a position in the students' group. It means that the aggressive situation students face pushes them to belong to the passive, aggressive or victims group. They asserted that although violent acts were negative, they had a positive implication for them in their community because those acts are experiences for them. They declared that aggressive reactions were inherent in every human being and that, in some occasions, aggression was necessary to survive in their community. Students believed that aggression was the solution in a place where people tried to make them submit; otherwise, they would become a victim of the aggressors.

In this part of the data analysis, some of the students' comments were connected to the previous category, in which aggression was linked to emotions and feelings. These concerns in the data gathered became a fundamental factor associated with misbehaving acts and power relationships among students. In this respect, De Angelis (2010) suggests that social consciousness is connected with emotions but also helps understand people's interaction in a group. It is pertinent to say that for students, aggressive acts were considered natural and common conditions generated because of their context. 
Table 3. Excerpts from groups 11, 10 and 3 to illustrate the second category.

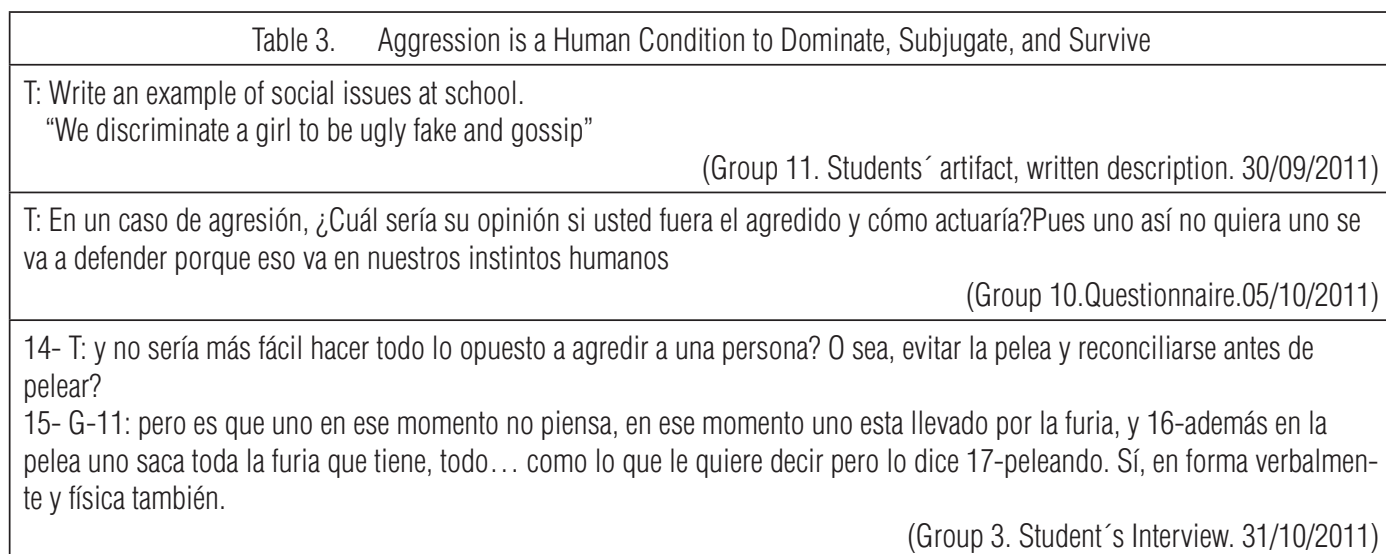

The findings show that students address aggression in terms of feelings, discrimination, rejection, fear, isolation, and revenge, among other concerns. In table 3, Group 11 accepted that they discriminated one of their partners; and ugliness, falsehood and gossip were just the justification of that aggression. Group 10 opined that independently of our sense of reason, in a case of aggression, they responded with aggression because violence was a human instinct, necessary to avoid other people's violence. Therefore, not all people assumed or accepted a similar position in the case of being part of an aggressive act, either as victims or as aggressors. On the other hand, Group 11 considered that aggression was the way they released their rage but it was also a way of expression.

The information provided by participants corresponded to a natural state, a situation that is expected to happen in contexts where people faced different social environments. To this respect, Durlark (1996) and De Angelis (2010) explain that aggression constitutes one of the ways humans use to dominate or control situations or people but how they react is the important finding. The former idea fits in the context of this research as students use aggression as a strategy to control or defend themselves from other students. Consequently, aggression might be an issue to take care of by teachers as part of their academic and social interest.
Most of the samples informed that students resorted to aggression because their emotions dominated their impulses and blocked their rational thinking. Spillane (2000) proposes that aggression is part of social interaction and emerges by different circumstances and in different forms, such as insults, physical contact, and gestures. In addition, the findings revealed that some students gained certain power by being aggressive.

Group 1 in Table 3 permitted us to understand how students showed their domination and control in their peer groups. In the excerpt, students revealed that "nerds" were a vulnerable population that served aggressors to abuse them and to demonstrate control or power among the group. The term aggression was understood as a human condition that empowered people to subjugate or get rid of a violent event. Spillane (2010) considers that aggressive acts are presented in all species and in humans especially in social interactions. Participants in Group 6 explained that with aggression students could set a precedent in which the ones who were aggressive were considered leaders because they had or imposed control, but students who were victims of aggressions belonged to the subjugate group. Contrary position in participants of Group 10 , who were survivors due to the fact that their aggressive behavior was not to dominate nor either 
Table 4. Excerpts from groups 1, 6 and 10 to illustrate the second category.

\begin{tabular}{|l|l|l|}
\hline \multicolumn{2}{|c|}{ Table 4. } & Aggression is a Human Condition to Dominate, Subjugate, and Survive \\
\hline $\begin{array}{c}\text { (Group 1. Students' artifact, written } \\
\text { description. 30/09/2011) }\end{array}$ & \multicolumn{1}{|c|}{ (Group 6. students Interview. 31/10/2011) } & \multicolumn{1}{c|}{ (Group 10. Questionnaire. 05/10/2011) } \\
\hline $\begin{array}{l}\text { T: Draw and write an example of social issues } \\
\text { at school }\end{array}$ & $\begin{array}{l}\text { T:¿Cuál es su punto de vista sobre la agresión } \\
\text { física o verbal acá en el colegio? }\end{array}$ & $\begin{array}{l}\text { T: En un caso de agresión, ¿Cuál sería su } \\
\text { opinión si usted fuera el agredido y cómo } \\
\text { actuaría? }\end{array}$ \\
$\begin{array}{l}\text { Ss: "In the school Tejares have several pro- } \\
\text { blems of discrimination, is how is abused the } \\
\text { students nerds of school. that is of bullying in } \\
\text { the school Tejares". }\end{array}$ & $\begin{array}{l}\text { Ss:"G-6. La agresión física más que todo es } \\
\text { por cómo defenderse o sea como usted tiene } \\
\text { un Puesto acá en el colegio dependiendo si } \\
\text { usted es el más duro 0 el más débil que se la } \\
\text { deja De todos eso es dependiendo la agresión } \\
\text { que se ve acá es como 5- para probar finura de } \\
\text { cómo es usted". }\end{array}$ & $\begin{array}{l}\text { Ss: "No me dejaría agredir y lo agrediría tam- } \\
\text { bién, por ultimo hablaria con alguien para que } \\
\text { nos ayudara a resolver el problema". }\end{array}$ \\
\hline
\end{tabular}

being submitted. The terms leaders, subjugate and survivors were assigned after categorizing the students' written descriptions.

All in all, this category explained that aggression was seen by students as a natural reaction that is inherent to any person and that, under certain circumstances, it is necessary as a self-defense mechanism, especially when emotions, feelings or thoughts are involved. Likewise, aggression empowered students not only to control, subjugate or survive in their context, but also to understand and learn from their difficult experiences. In the upcoming lines I focused on the importance of reflection while writing about their context.

\section{Writing as a Means of Growing as Citizens}

This last stage gives an account of students' writing development during the inquiry process about social issues in and out of the school. The data collected revealed that students identified the responsibility of adults and themselves in reducing aggressive behaviors in their institution and in other contexts like home.

Table 5. Excerpts from groups 2, and 9 to illustrate the third category

\begin{tabular}{|c|c|}
\hline (Group 2. Students' artifact, written description. 12/09/2011) & (Group 9. Questionnaire 05/10/2011) \\
\hline $\begin{array}{l}\text { T: List the problems you observe in your community. Then choose } \\
\text { one and describe it. } \\
\text { SS: Problems: Drugs. Robbery, Insegurity, Gang, Fights, Early } \\
\text { pregnancy. } \\
\text { Early pregnancy: the positions of people in regards to the early } \\
\text { pregnancy it is complex because people recognized that this } \\
\text { problem is because of the lack of confidence at home, parens not } \\
\text { know the stop of his daughters and students not have concien- } \\
\text { se of the consecuences that to have sexual relations like early } \\
\text { pregnancy. }\end{array}$ & $\begin{array}{l}\text { T: do you think it is possible to use the strategy used by the stu- } \\
\text { dent from the movie (Pay Forward) in a context like Tejares? Why? } \\
\text { Ss: no, because the people not colaborate wyth other people. For } \\
\text { example teachers are rude when your students acuse other teacher } \\
\text { for maltrato }\end{array}$ \\
\hline
\end{tabular}


In Table 5 Group 2, students described different social concerns they observed in their community and they focused on early pregnancy, pointing out that this issue was associated with the lack of responsibility and confidence between parents and teenagers. The excerpt showed some language mistakes like "parents not know the stop of his daughters" referring to parents who do not know where their children are. This excerpt showed that language was not a barrier to speak their minds as students could give their opinions and the topic motivated them to do it. In Group 9, students analyzed a strategy used by a student in the film "Pay It Forward" in which the film presented cooperation and mutual help as a strategy to enhance citizenship, however, students affirmed that in their context adults showed negligence in the solution of their problems.
The samples demonstrated that student's context and EFL learning had a relevant connection in which students used the L2 to express their own realities. This made them understand and use the language meaningfully. To this regard, McLaren (1989) states that education goes beyond the responsibility of providing students with academic learning. He asserts that schools are places where multiple behaviors and issues take place, and teachers have the responsibility to observe and make students able to understand and interact with different people, situations, and cultures while getting instructed. In addition, the findings revealed that inquiry opened spaces for students to provide ideas and proposals to solve problems like aggression in a school.

Table 6. Excerpts from groups 11,8 and 7 to illustrate the third category.

\begin{tabular}{|l|l|l|}
\hline \multicolumn{2}{|c|}{ Table 6. Writing as a means of Growing as Citizens } \\
\hline \multicolumn{1}{|c|}{$\begin{array}{l}\text { Group 11. Students' artifact, written opinion. } \\
\text { 08/11/2011) }\end{array}$} & (Group 8. Students' questionnaire. 08/11/2011 & \multicolumn{1}{c|}{$\begin{array}{c}\text { (Group 7. students' questionnarie. } \\
\text { 08/11/2011) }\end{array}$} \\
\hline $\begin{array}{l}\text { T: Cómo puede usted contribuir en la dismi- } \\
\text { nución de agresiones físicas y verbales de su } \\
\text { colegio? }\end{array}$ & $\begin{array}{l}\text { T: Write some ideas to help the school to } \\
\text { reduce physical or verbal aggressions? }\end{array}$ & $\begin{array}{l}\text { T: Write some ideas to help the school to } \\
\text { reduce physical or verbal aggressions? }\end{array}$ \\
$\begin{array}{l}\text { Ss: Yo pienso que participar en eventos que } \\
\text { nos reintegren, o sea que no sea hacer trabajos } \\
\text { de grupo, sino actividades que nos lleven a in- } \\
\text { tegrarnos incluso con los que no nos llevamos } \\
\text { bien, porque los profes digamos se preocupan } \\
\text { por notas pero no por dejar una actividad que } \\
\text { solucione problemas del curso. }\end{array}$ & $\begin{array}{l}\text { Ss: Make campaigns or forums of not ag- } \\
\text { gression because of verbal aggression people } \\
\text { pass to physical aggression and we can invite } \\
\text { people that has fight before to say experiences. }\end{array}$ & $\begin{array}{l}\text { Ss: we say that l can heing the "padri- } \\
\text { no students in } 6^{0} \text {. We are bigger and we can } \\
\text { help students that are aggressors. Assesoring } \\
\text { in your problems, for example. }\end{array}$ \\
\hline
\end{tabular}

As shown in Table 5, Group 11 considered that class activities must promote integration and peaceful environments among all the students. They thought that most activities were academic and teachers did not help in transforming social realities in their institution. Groups 8 and 7, on the contrary, pointed at the implementation of workshops, campaigns, and forums in which they could hear experiences from their peers in order to help their institution to be aware and to prevent violence issues.

Consequently, the reflections revealed their awareness in terms of cooperation to reduce aggressive behaviors at school and the writing progress was notorious as students were involving their context in the learning of English. Marshall and Klein (2009) contemplate that changes are possible when students' context guide academic processes. They consider that social problems must be seen as an advantage that allows students to assume a critical position about the problems they face. Social issues and student context are good components to keep in mind in the curriculum.

By and large, the last category allowed me to conclude that using real contexts favored the 
development of students' writing skills in EFL, and permitted teacher and students to understand that building a better society depended on everybody. Likewise, it permitted to hear students' voices and their contribution to reduce aggression issues in their institution. Having displayed the data analysis, the last sections summarize the conclusions and the main pedagogical implications.

\section{Conclusions}

This qualitative study was conducted with the intention of responding to what students' writings revealed about social awareness when inquiring about physical and verbal aggression in a public school in Bogota. Likewise, it aimed to describe how this process contributed to the teaching and learning practices in EFL. The results of this study revealed three main categories. The first showed participants' social awareness and concerns about their context in "Building consciousness from unpredictable human behaviors in the community context", the second one their opinions about aggression in "Aggression is a human condition to dominate, subjugate and survive", and the third one their reflections and intentions in "Writing as a means of growing as citizens".

Responding to the main question, the study showed that students began a process of developing rationality and sensitivity towards violent acts presented in their institution, as well as an understanding of the consequences. Students assumed positive and negative positions in regards to aggressive behaviors. Some of their reflections pointed out that aggression was no the means to solve a problem but sometimes it was unavoidable in their context.

They considered that one way to reduce violence at school was making people understand their context by sharing experiences with others. They asserted that aggression was an impulse to try to deal with situations they could not handle with dialogue. They concluded that they were aware of the consequences of violence, but the hard context they faced obliged them to act aggressively. They criticize the way the school dealt with aggressive issues and they also showed their intention to help the institution by guiding or telling their experiences to small kids. They considered their experiences as a teaching strategy to avoid violence at school.

Students evidenced engagement and commitment in regards to their social and educational context by showing and taking critical positions that enhanced personal growth, social awareness, and future social transformation. According to the data collected, students showed their intention to change situations that affected their behaviors at school and they stated that changes were possible if teachers and parents paid more attention to their personal growth rather than academic concerns. Aspects such as selfemotional control and adult involvement were reasons that, according to the participants, lacked attention from the institution and contributed to physical and verbal aggressions in their school.

In relation to the sub-question, how do students' develop better EFL writing when inquiring about verbal and physical aggression inside their institution, the study revealed three important aspects that contributed to the process of reading and writing in EFL. The first was that language was not a barrier in expressing their thoughts; on the contrary, participants demonstrated willingness and interest in expressing their ideas in English. In this regard, Freire (1987) states that the role of literacy is to let people have a voice in society. Writing was not just an activity that involved writing as such; it was a moment for students to speak their minds. They wrote about contextualized conditions by using different topics learned in the English class (bullying, verbal and physical violence at home, teachers' attitudes, and grammar content, among other topics).

The second aspect was related to grammar and vocabulary. Since the beginning of the implementation, grammar and lexicon were a deficiency which made 
students' writing very slow. Through the activities students began to internalize words and understand the use of grammar structures. In this stage, the teacher's role was to solve doubts and to make English practical in their context. The application of grammar and vocabulary in a real context allowed them to write longer and more coherent paragraphs without the constant use of the dictionary.

The third aspect had to do with teamwork and first language use. Through the exercises done by participants, I observed that inquiry pushed them to think about situations and actions that were not properly established in regular English activities (reading their context, reflecting on their social problems, etc.) (Robertson \& Bloome, 1998). As students were developing the inquiry cycle (Short et al., 1996), they were contrasting the L1 and the L2 and recalling the language to write their ideas. Switching between the two languages helped students better understand grammar tenses. This process involved the cooperation of the whole group to revise grammar and coherence in their ideas.

To conclude, and based on this research experience, I can say that this study that involved inquiry and social concerns like physical and verbal aggression contributed to students' reflection on social problems. Although this research did not solve the problematic situation presented at Tejares school, it served many purposes. The first was to explore students' opinions about aggression and the second to find possible solutions provided by the students themselves. Third, the study recognized that aggression occurs partly because we as adults do not pay serious attention to students' feelings and needs. The fourth purpose was to understand that students' emotions might represent a solution to the physical and verbal problems at Tejares school (C'Sóti, 2009). Finally, this study showed the reciprocity among inquiry, literacy practices in EFL, and social contexts.

\section{Pedagogical implications}

Looking at the constant incidents of violence in public education, it is important to consider that students are affected by different concerns like personal feelings, emotions, and lack of adult involvement. These concerns were evidenced during the research study and could be part of an interdisciplinary project that involves different areas of knowledge and that permits students to observe and analyze aggression issues by taking into account different perspectives (personal, emotional, contextualized, etc.).

It is necessary for teachers and parents to participate actively in the personal growth of students, paying attention to their behaviors and emotions and not only their academic process (Hindin, 2010; Hull $\varepsilon$ Shultz, 2001). This involvement can help reduce problems students face at a personal, emotional, or social level. It is also important that teachers help in the social formation of students and teach contextualized content. This opens spaces for students to analyze their social problems and form opinions, making their voices important to the teachers and the institution. As mentioned by Lerner (2001), learning in schools is meaningful and fruitful when there is an interaction between the context and the class content.

Inquiry as a pedagogical intervention is a time consuming process but it is fundamental and useful in any school setting. Inquiry permits students to explore issues of their interest by following an organized model where each step of the model guides and complements the students' work. Letting students inquire about social issues or other topics makes classes more dynamic because students decide, work on, and explore things on their own with the guidance of the teacher; students take direct action in the process of learning. Inquiry in the EFL teaching and learning process addresses teachers and students to work cooperatively, to apply and understand English content and to build meaningful 
knowledge. With inquiry, teachers can adjust, and re-evaluate the teaching and learning practices used in their institutional syllabus.

Additionally, it is indispensable to work more on using social components as part of the curricula. Social issues provide a lot of information from which teachers can take advantage; this applies not only to EFL, but to most school subjects. Sometimes teachers ignore what is beyond our school doors and the responsibility we have to ameliorate some harsh conditions our learners face. Based on this research experience, I believe it is important to evaluate our practices as teachers in order to identify and understand the magnitude of linking students' realities to the school program and the learning process.

As a result, inquiry and reflection on social issues should be valuable elements to be implemented in the process of writing in EFL. This study also showed that it is important to start implementing pedagogical and social changes inside and outside Tejares school. In my opinion, the lack of integration between students' realities and curricula is one of the main weaknesses evident at school. However, the result of this research is a good starting point that serves to implement actions in the way teachers guide their daily teaching practices. Narratives about students' aggressive experiences in EFL, for example, may be a good opportunity for students to reflect upon their attitudes and behaviors, and for teacher, it could be a strategy to enhance English language skills.

\section{References}

Auerbach, C., \& Silverstein, L. (2003). Qualitative data. An introduction to coding and analysis:Coding the mechanics. New York, NY: New York University Press.

Banchi, H. \& Bell, R. (2008). The Many Levels of Inquiry. Science and Children. Retrieved from http://www. ode.state.or.us/teachlearn/subjects/science/resources/msef2010- level_of_inquiry.pdf

Baynham, M. (1995). Investigating literacy in social contexts. Defining literacy: Models, myths and metaphor. City, England: Longman.
Bello, I. (2012). A language -in - use study of EFL students' social discourses in project-based learning. Colomb. Appl. Linguistic. J, 14(1), 108-126.

Bibens, R. (1980). Using inquiry effectively: Theory into practice. Teaching Methods:

Broadway, State: Hampton Press.

Burns, A. (1999). Collaborative action research for English teachers. Cambridge, UK: Cambridge University Press.

Csóti, M. (2009). Developing children's social, emotional and behavioral skills. Available from_http://books. google.es/books?id=OLGHNAAACAAJ\&dq=cs \% C3\%B3ti+mariana\&hl=e\&ei=2RjZTcrPE4GatwfOqo $\mathrm{HpDg} \& \mathrm{sa}=X \&$ oi=book_result\&ct $=$ result\&resnum $=5$ \&ved $=0$ CD8Q6AEwBA

De Angelis, T. (2010). Social Awareness plus emotional skills. Successful Kid. Retrieved from http://www. apa.org/monitor/2010/04/classrooms.aspx.

Dey, lan. (1993). Qualitative data analysis: A user-friendly guide for social scientists. New

York, NY: Routledge Taylor \& Francis Group.

Durlark, J. (1996). The effects of childhood sexual abuse on female sexuality: A model of Intervention. Retrieved from ttp://www.aic.gov.au/events/aic\%20 upcoming\%20events/1999/ /media/conferences/ rvc/ marendaz.ashx

Facione, P. (1998). Critical thinking: What it is and why it counts. Retrieved from http:/insightassessment. com/pdffiles/what/\&why98.pdf

Freeman, D. (1998). Doing teacher research: From inquiry to understanding. Boston, MA: Heinle, Cengage Learning.

Freire, P. \& Macedo, D. (1987). Literacy: Reading the word and the world. London, UK: Bergin and Garvey.

Gay, L., Mills, G., \& Airasian, P. (2009). Educational research. Competencies for analysis and applications. New Jersey, US: Pearson.

Giroux, H. (1988). Teachers as intellectuals: Toward a critical pedagogy of learning. Westport, CT: Greenwood Publishing Group.

Green, J. (1998). Language and social processes. In E. Robertson \& D. Bloom (Eds.), Students as researches of culture and language in their own communities (pp. 9-27).Broadway, State: Hampton Press. 
Hindin, A. (2010). Linking home and school: Teacher candidates' beliefs and experiences. The school community journal, 20(2), 83-102.

Ho, C. (2010). Intergenerational learning (between generation $X \&$ y) in learning families: A narrative inquiry. Canadian center of science and education, 3(4), 54-76.

Hull, G., \& Shultz, K. (2001). Literacy and learning out of school: A review of theory and research. American Educational Research Association, 71(4), 575-611.

Jockson, K.M. (2006). There's a better word: Urban youth rewriting their social worlds through poetry. Journal of Adolescent \& Adult Literacy, 49(8), 132155. doi:10.1598/JAAL.49.8.6

Lerner, D. (2001). Leer y escribir en la escuela: Lo real, lo posible y lo necesario.City, Mexico: Fondo de Cultura Económica.

Lewis, S., \& Bernstein, Y. (2009). Breaking the silence: Critical literacy and social action. English Journal, 98(4), 109-115.

Marshall, J., \& Klein, A. M. (2009). Lesson in social action: Equipping and inspiring students to improve their world. Location: Heldref Publications.

Maxwell, J. (1996). Qualitative research design: An interpretative approach. California, US: Sage Publication.

McLaren, P. (1989). Life in Schools: An introduction to critical pedagogy in the foundation of education. Boston, MA: Pearson Allyn and Bacon.

Millan, C. (2010). El problema de la educación en Colombia. Available from http://censura20. com/2010/03/22/el-problema-de-la-educacionen-colombia/

Olson, D. \& Torrance, N. (1995). Cultura escrita y oralidad. City, Spain: Gedisa.

Parga. F. (2011). Cooperative structures of interaction in a public school EFL classroom in

Bogota. Colomb. Appl. Linguistic. J, 13(1), 24-38.

Phillip. W. J. (1998). International policies for third world education: UNESCO, literacy and development.
Available from http://books.google.com/books? $\mathrm{hl}=\mathrm{es} \& \mathrm{l}=\& \mathrm{id}=8 \mathrm{MUOAAAAQAAJ} \& \mathrm{oi}=\mathrm{fnd} \& \mathrm{pg}=\mathrm{PP}$ 13\&ot s=5GU_FV-hOG\&sig=sMJgACs5doCYZp onGqw6plsI7XI research. American Educational Research Association, 71(4), 575 - 611.

Robertson, A., \& Bloome, D. (1998). Students as researchers of culture and language in their own communities. City, State: Hampton Press.

Selman, R. (2011). Teaching social awareness. Retrieved from http://www.gse.harvard.edu/news/ features/selman02012003.html

Shepard, T. (2000). Sociology: Understanding a diverse society. Florence, KY: Thomson

Wadsworth.

Short, K., Burke, C., \& Harste, J. (1996). Learning together through inquiry.

Portland, OR: Stenhouse Publishers.

Spillane, E. (2000). From parent verbal abuse to teenage physical aggression. Child and Adolescent Social Work Journal, 17(6), 411-430. doi: 10. 1023/A: 1026427710320.

Strauss, A., \& Corbin, J. (1990). Basis of qualitative research: Ground theory, procedures and techniques. London, UK: Seige Publications.

SUIVD Observatorio de convivencia y seguridad ciudadana (2008). Convivencia y seguridad en ámbitos escolares de Bogotá. Bogotá: Subsecretaría de asuntos para la convivencia y seguridad ciudadana. Alcaldía Mayor de Bogotá.

Teutsch, D. (1997). (Re)constructing masculinity in a new linguistic reality. New York, NY: Gruyter Mouton.

Uno, G. (1990). Inquiry in the classroom. BioScience, 11, 841-843.

White, D. \& Fitzsimmons, P. (2005). Assessment in the inquiry classroom. In R. Audet \& L. Jordan, (Eds.), Integrating inquiry across the curriculum (pp. 157 - 174). California, US: Corwin Press. 


\section{Appendix 1}

\section{Formato de consentimiento padres de familia}

Señor (a)

Padre / Madre de Familia:

Colegio IED LOS TEJARES Jornada Mañana Día___ Mes___ Año ___ _ _ _ _

Cordial saludo:

A través de la presente, deseo informarle que en la clase de Inglés con el grupo 1001 que está a mi cargo, se realizará un proceso de investigación que busca identificar aspectos sociales encaminados a la concientización del estudiante acerca de las problemáticas que lo rodea y su posible consecuencia dentro de las aulas de clase. Por otro lado, se busca también, ayudar al estudiante en sus prácticas lecto - escritoras en Inglés. Dicho proceso de investigación se ajusta con lo propuesto en el PEI del Colegio Tejares, cuyos pilares se fundamentan en la construcción de la excelencia para una sociedad solidaria y productiva.

La recolección de datos se hará durante el año académico (2011), esta incluye entrevistas, video grabaciones, notas de campo y reportes escritos en cuaderno o en algunos formatos. La información será utilizada para documentar y reportar el proceso de investigación que adelanto en la Maestría en lingüística aplicada a la enseñanza del inglés en la Universidad distrital francisco José de Caldas.

Con lo expuesto anteriormente, solicito su autorización para que los datos proporcionados por los estudiantes sean socializados sin detrimento de su identidad.

Agradezco su valiosa colaboración para el desarrollo de esta propuesta investigativa

Atentamente:

Luzmel Alexánder Pérez Pérez.

Docente de Inglés de la jornada mañana.

Yo

(a), menor de edad

docente Luzmel Alexánder Pérez Pérez con el curso identificado (a) con C.C.

de

Autorizo a mi hijo para que participe en el proceso de investigación adelantado por el jornada mañana del Colegio Tejares. 


\section{Appendix 2}

\section{Pedagogical Intervention Weekly Schedule}

\begin{tabular}{|c|c|c|c|c|}
\hline $\begin{array}{l}\text { Inquiry stage } \\
\text { (Short, 1996) }\end{array}$ & Date & Task & Description of the activity & Materials \\
\hline $\begin{array}{l}\text { Building from the } \\
\text { known }\end{array}$ & $19 / 8 / 11$ & $\begin{array}{l}\text { Task 1: } \\
\text { Listing social issues that } \\
\text { students face at school } \\
\text { and in the community. }\end{array}$ & $\begin{array}{l}\text { In groups of } 3 \text { or } 4 \text {, participants suggested a list of topics related to } \\
\text { social issues they observed in different communities, school, family, } \\
\text { and neighborhoods. Students gave explanation of those issues. }\end{array}$ & $\begin{array}{l}\text { - Students' experiences at } \\
\text { school and community } \\
\text { - Questionnaires }\end{array}$ \\
\hline \multirow{3}{*}{$\begin{array}{l}\text { Taking the time to } \\
\text { find questions for } \\
\text { inquiry }\end{array}$} & $16 / 9 / 11$ & $\begin{array}{l}\text { Task 2: } \\
\text { Introduction and example } \\
\text { of how to formulate and } \\
\text { question. }\end{array}$ & $\begin{array}{l}\text { The English teacher showed an example (movie Pay It Forward) } \\
\text { where he talked about an important issue in society (bullying). Based } \\
\text { on the issue, he explained how people could see things in relation to } \\
\text { themselves and how questions could appear from that topic. Then, } \\
\text { along with the students, he wrote questions. He focused students' } \\
\text { attention on the coherence and intention of the questions. Also, he } \\
\text { reminded students about the type of questions (open and closed). } \\
\text { After that, students represented their understanding of bullying } \\
\text { through drawings, and started formulating their own questions about } \\
\text { bullying. At the end of the activity, some questions were analyzed and } \\
\text { they determined the most appropriate question to use in an inquiry } \\
\text { process. }\end{array}$ & $\begin{array}{l}\text { - Movie "Cadena de } \\
\text { favores" } \\
\text { - Articles, newspapers and } \\
\text { internet video clips about } \\
\text { bullying. } \\
\text { - List of possible } \\
\text { questions based on the } \\
\text { articles and the movie } \\
\text { - Cardboard to draw and } \\
\text { to write questions }\end{array}$ \\
\hline & 19/09/11 & $\begin{array}{l}\text { Task 3: } \\
\text { Selecting a social issue } \\
\text { - proposing an inquiry } \\
\text { question. }\end{array}$ & $\begin{array}{l}\text { Based on the information gathered in the first stage, students (groups } \\
\text { of } 3 \text { ) and teacher agreed to work on two issues, verbal and physical } \\
\text { aggression. Students worked in groups and picked one issue to work } \\
\text { on. Then, each member created a question and after some time, the } \\
\text { whole group analyzed which questions covered what they wanted to } \\
\text { know about the topic. }\end{array}$ & $\begin{array}{l}\text { - Students' ideas } \\
\text { - Questions on board }\end{array}$ \\
\hline & $23 / 9 / 11$ & $\begin{array}{l}\text { Task } 4 \\
\text { Building and rebuilding } \\
\text { the inquiry questions to } \\
\text { start the process.: }\end{array}$ & $\begin{array}{l}\text { Students began to shape the questions they formulated to respond } \\
\text { throughout and at the end of the inquiry process. Each group } \\
\text { established the question that better fit their intentions in regards to } \\
\text { the selected issue. }\end{array}$ & - Students' proposals \\
\hline $\begin{array}{l}\text { Gaining new } \\
\text { perspectives } \\
\text { and attending to } \\
\text { difference }\end{array}$ & $30 / 9 / 11$ & $\begin{array}{l}\text { Task 5: } \\
\text { Finding information } \\
\text { using different sources. }\end{array}$ & $\begin{array}{l}\text { After defining the key question, participants talked about the sources } \\
\text { in which they could find information about the topic. One assignment } \\
\text { was to find the information to be shared next class. }\end{array}$ & $\begin{array}{l}\text { - TV programs } \\
\text { - Videos } \\
\text { - Internet } \\
\text { - Newspapers }\end{array}$ \\
\hline \multirow[t]{2}{*}{$\begin{array}{l}\text { Sharing what was } \\
\text { learned }\end{array}$} & 03/10/11 & $\begin{array}{l}\text { Task 6: } \\
\text { Sharing information } \\
\text { using communicative } \\
\text { English skills. }\end{array}$ & $\begin{array}{l}\text { In groups, students read the information they found. They organized } \\
\text { a chart in which they wrote the author's name, title of the text, the } \\
\text { year, and the source. They summed up the main ideas from the } \\
\text { information and decided if it was relevant or not for their inquiry } \\
\text { project. They had the opportunity to help each other in clarifying } \\
\text { doubts about the information and aspects of the language. Students } \\
\text { who found information from videos, internet, music, etc., had to } \\
\text { write a brief summary to share to the group. The teacher helped them } \\
\text { correct language mistakes and socialize their findings. }\end{array}$ & $\begin{array}{l}\text { - Articles } \\
\text { - Internet } \\
\text { - Interviews } \\
\text { - Teacher's presentation } \\
\text { - Music }\end{array}$ \\
\hline & $4-5 / 10 / 11$ & $\begin{array}{l}\text { Task 7: Inquiring and } \\
\text { interviewing people from } \\
\text { different communities. }\end{array}$ & $\begin{array}{l}\text { The next task in this inquiry process was to get more data about the } \\
\text { topic. Students organized short interviews to be applied to members } \\
\text { of the school. (better if they interview people who have participated } \\
\text { in acts of aggression). This exercise allowed them to hear direct } \\
\text { opinions from primary sources. }\end{array}$ & $\begin{array}{l}\text { - Interviews (done by } \\
\text { students) } \\
\text { - Tape recorders } \\
\text { - Notes }\end{array}$ \\
\hline
\end{tabular}




\begin{tabular}{|c|c|c|c|c|}
\hline & $\begin{array}{l}\text { 7-/10/11- } \\
\text { 20/10/11 }\end{array}$ & $\begin{array}{l}\text { Task } 8 \\
\text { Writing and sharing } \\
\text { reflections on the issues } \\
\text { they are inquiring } \\
\text { about.: }\end{array}$ & $\begin{array}{l}\text { In this activity, participants were asked to write short reflections after } \\
\text { reading, watching, or listening to information about the topics they } \\
\text { chose. This stage opened an opportunity for students to know their } \\
\text { partners' work and points of view about the issues. This was also an } \\
\text { open space for reasoning, questions, and opinions. They were able } \\
\text { tocriticize and defend their ideas. This exercise was very important to } \\
\text { point out the importance of listening and respecting others 'opinions. }\end{array}$ & - Reflection logs \\
\hline Planning new inquiry & $\begin{array}{l}\text { 21/10/11- } \\
25 / 10 / 11\end{array}$ & $\begin{array}{l}\text { Task 9: } \\
\text { Debating and pointing } \\
\text { out personal points of } \\
\text { view. }\end{array}$ & $\begin{array}{l}\text { In this part of the inquiry process, students were expected to } \\
\text { answered the question they posed, as well as the proposition of } \\
\text { new questions to continue, or start a new inquiry. They had to } \\
\text { prepare a formal presentation, given the result of their inquiry. In the } \\
\text { presentation, students and another English teacher would be present. } \\
\text { Participants decided how to present. }\end{array}$ & $\begin{array}{l}\text { - Computer } \\
\text { - Cardboards } \\
\text { - Videos } \\
\text { - Writing posters } \\
\text { - Portfolios }\end{array}$ \\
\hline $\begin{array}{l}\text { Taking thoughtful } \\
\text { new action }\end{array}$ & $\begin{array}{c}\text { 27/10/11- } \\
8 / 11 / 11\end{array}$ & $\begin{array}{l}\text { Task 10: } \\
\text { Exposing findings. } \\
\text { Comment about the } \\
\text { process and new ideas. }\end{array}$ & $\begin{array}{l}\text { The last part of the process consisted of a written reflection } \\
\text { about their understanding and awareness of social issues. They had } \\
\text { to explain how social issues like physical and verbal aggression } \\
\text { influenced their behavior at school. They also wrote positive and } \\
\text { negative things about the process they carried out. They mention } \\
\text { other possible questions that can emerge from this initial inquiry. }\end{array}$ & - Final Written report \\
\hline
\end{tabular}

THE AUTHOR

LUZMEL ALEXÁNDER PÉREZ PÉREZ, holds an MA degree in Applied Linguistics to TEFL (2012) and a BA as Modern Language teacher (2005) from Universidad Distrital. He has participated in an international program as a Camp Counselor with the (YMCA) Young Men Christian Association (2004 - 2006). His fields of interest are mainly on literacy studies and teaching development. He is currently working for ILUD (Instituto de Lenguas de la Universidad Distrital) and Secretaría de Educación de Bogotá. 